\title{
Mosquito Survey in the Campus Area of Universitas Padjadjaran Jatinangor in September to November 2016
}

\author{
Lia Faridah, ${ }^{1}$ Radiah Baizura, ${ }^{2}$ Sri Yusnita Irda Sari ${ }^{3}$ \\ ${ }^{1}$ Department of Microbiology and Parasitology, Faculty of Medicine, Universitas Padjadjaran, Bandung, \\ Indonesia, ${ }^{2}$ Faculty of Medicine, Universitas Padjadjaran, Bandung, Indonesia, ${ }^{3}$ Department of Public Health, \\ Faculty of Medicine, Universitas Padjadjaran, Bandung, Indonesia
}

\begin{abstract}
Sumedang regency reported being one of dengue endemic areas in West Java. The number of dengue fever patients in Sumedang District General Hospital increased in the last quarter of 2015. Universitas Padjadjaran (Unpad) is one of most significant areas in Jatinangor Sumedang where many people are doing their activity day and night. The purpose of the study was to identify what types of mosquito genera exist in Unpad campus according to the time and location. A field survey was conducted at 22 locations in Unpad campus using modified electric light trap placed indoor and outdoor at each site from September to November 2016. The modified electrical trap was turned on for 24 hours and samples collected every 12 hours. Mosquitoes trapped were put into the plastic cup, labeled according to time collected, and brought to Parasitology Laboratory of Unpad for identification. The study result identified four types of mosquito genera which were Culex spp. (405), Armigeres spp. (70), Aedes spp. (33), and Anopheles spp. (10). Prevention toward potential breeding sites and protection using window net should be considered to reduce the risk of vector-borne diseases. In conclusion, Aedes spp. is the most active mosquito during the day while Culex spp. and Armigeres spp. are the most active mosquito during the night.
\end{abstract}

Key words: Aedes spp., Anopheles spp., Armigeres spp., Culex spp., mosquito

\section{Survei Nyamuk di Kawasan Kampus Universitas Padjadjaran Jatinangor pada Bulan September-November 2016}

\begin{abstract}
Abstrak
Kabupaten Sumedang dilaporkan sebagai salah satu daerah endemik demam berdarah di Jawa Barat. Jumlah pasien demam berdarah yang datang ke Rumah Sakit Umum Daerah Sumedang meningkat dalam tiga bulan terakhir pada tahun 2015. Universitas Padjadjaran (Unpad) merupakan salah satu wilayah yang terluas di Jatinangor Sumedang sebagai tempat banyak orang melakukan aktivitas pada siang dan malam hari. Tujuan penelitian ini adalah mengidentifikasi jenis genera nyamuk yang ada di kampus Unpad Jatinangor berdasar atas waktu dan lokasi. Survei lapangan dilakukan pada 22 lokasi di kampus Unpad Jatinangor pada bulan September-November 2016 menggunakan perangkap nyamuk cahaya yang dimodifikasi. Perangkap nyamuk ditempatkan di dalam dan luar ruangan untuk setiap lokasi. Perangkap nyamuk dipasang selama 24 jam, kemudian nyamuk dikumpulkan setiap 12 jam. Nyamuk yang terperangkap dikumpulkan dan dimasukkan ke dalam cangkir plastik, diberi label sesuai dengan waktu pengambilan, kemudian dibawa ke Laboratorium Parasitologi Unpad untuk diidentifikasi. Hasil penelitian menunjukkan 4 genera nyamuk ditemukan di kampus Unpad Jatinangor, yaitu Culex spp. (405), Armigeres spp. (70), Aedes spp. (33), dan Anopheles spp. (10). Pencegahan pada tempat yang berpotensi menjadi sarang nyamuk dan perlindungan menggunakan kawat nyamuk pada jendela harus dipertimbangkan untuk menurunkan risiko penyakit tular vektor. Simpulan penelitian ini, Aedes spp. merupakan nyamuk yang paling aktif pada siang hari serta Culex spp. dan Armigeres spp. yang paling aktif pada malam hari.
\end{abstract}

Kata kunci: Aedes spp., Anopheles spp., Armigeres spp., Culex spp., nyamuk

Received: 26 May 2017; Revised: 6 December 2017; Accepted: 12 December 2017; Published: 27 December 2017

Correspondence: Lia Faridah, dr., M.Si. Department of Microbiology and Parasitology, Faculty of Medicine, Universitas Padjadjaran. Jln. Raya Bandung-Sumedang km 21, Jatinangor, Sumedang, West Java, Indonesia. Phone: (6222) 7796373; 2032170. Fax: (6222) 7795595; 2037823. Mobile: 628122019367. E-mail: lia.faridah@unpad.ac.id; liafaridah2013@gmail.com 


\section{Introduction}

Mosquito listed as the world's deadliest animal that has put to death many people worldwide each year. ${ }^{1}$ They transmit numerous pathogens and parasites to human. These pathogens will not cause any dangerous effect on the mosquitoes, yet they reproduce inside them. Indonesia is a tropical country that provides a suitable habitat for breeding the mosquitoes since the weather condition has high humidity. This situation may cause mosquito-borne diseases such as malaria, dengue fever, filariasis, encephalitis, and chikungunya. These are the most common diseases that could attack human and become the most important public health problem. Indonesia was known as at most-risk in the spread of dengue fever and malaria. ${ }^{2}$

In 2015 specifically, there were 7,594 cases of dengue fever and 89 cases of malaria in overall West Java. In Sumedang regency there were 253 cases of dengue fever and 2 cases of malaria. ${ }^{3}$ In the same year, the whole area of Sumedang regency reported as endemic for dengue. ${ }^{4}$ The number of dengue fever patients was reported increasing without significant extra-ordinary events. ${ }^{5}$ Furthermore, in the last quarter of 2015, the number of dengue fever patients coming to Sumedang District General Hospital increased. ${ }^{6}$ In Jatinangor subdistrict, data in 2015 from primary health center showed that at least $3-5$ people were affected with dengue fever in the middle of the year. ${ }^{7}$

Universitas Padjadjaran (Unpad) campus is located in Jatinangor Sumedang and comprises an overall area of approximately 175 hectares. It is the main campus of Unpad with 16 faculties. Besides academic buildings in each faculty, there are also a rectorate building, student dormitories, a stadium, lakes, and a mosque. The human activities in these areas might create mosquitobreeding sites. There is also an animal shelter in the campus belonging to the Faculty of Animal Husbandry. Besides humans, mosquito also bites on animals such as cows and goats. There are also paddy fields, farms, rivers, and lakes near the campus. As mosquitoes need water to complete the process of metamorphosis, there is a possibility that mosquitoes use these places as their breeding sites.

Every year, there will be thousands of new students at Unpad. It is possible that some of the students might come from the endemic area of mosquito-borne diseases and transmit the diseases, as human movement is one of the ways to spread the disease. The virus can be transmitted either from an infected mosquito to human or from viraemic human to an uninfected mosquito. ${ }^{8}$ Furthermore, Unpad is one of the campuses located in Sumedang district. So, as the status of endemic dengue has been reported by all health centers in Sumedang regency, all of the students who are studying in Unpad Jatinangor are at risk to develop the disease. As an academic institution, Unpad should be participating in giving efforts to mosquito control to prevent the transmission of mosquito-borne diseases to both the community and students, especially in Jatinangor campus. All of those reasons prompt a survey of the adult mosquito to conduct in Unpad campus, Jatinangor. The purpose of the study was to identify what types of mosquito genera exist in Unpad campus according to the time and location.

\section{Methods}

The collection of mosquitoes conducted at 22 locations in Unpad Jatinangor campus as a representation of campus area. The study design was a descriptive study with entomology survey method. The sample population was the mosquitoes which exist in the study locations. Mosquitoes were collected using a modified electric light trap which was put outdoor and indoor at each site.

There were 22 locations chosen to represent Unpad Jatinangor campus. The locations further divided into five subtypes which were offices, academic buildings, dormitories, public places, and animal sheds. This is a descriptive study, no statistical analysis used or this study.

Electric light trap with sugar fermentation as mosquito attractant was put indoor and outdoor at each location. The location was chosen based on inclusion criteria such as shady, cold and humid area, the presence of human near/in a building, near to trees or shrubs, and possible breeding sites. The exclusion criteria were area exposed to wind, smoke, insecticide, and near to competing for light sources such as artificial light. The mosquito trap was turned on for 24 hours. Every 12 hours (1 a.m. to 12 a.m. and 1 p.m. to 12 p.m.), all the mosquitoes trapped inside and outside the building collected and inserted into a plastic cup. Each plastic cup labeled according to time collected. The sample taken brought to the parasitology laboratory for identification. 


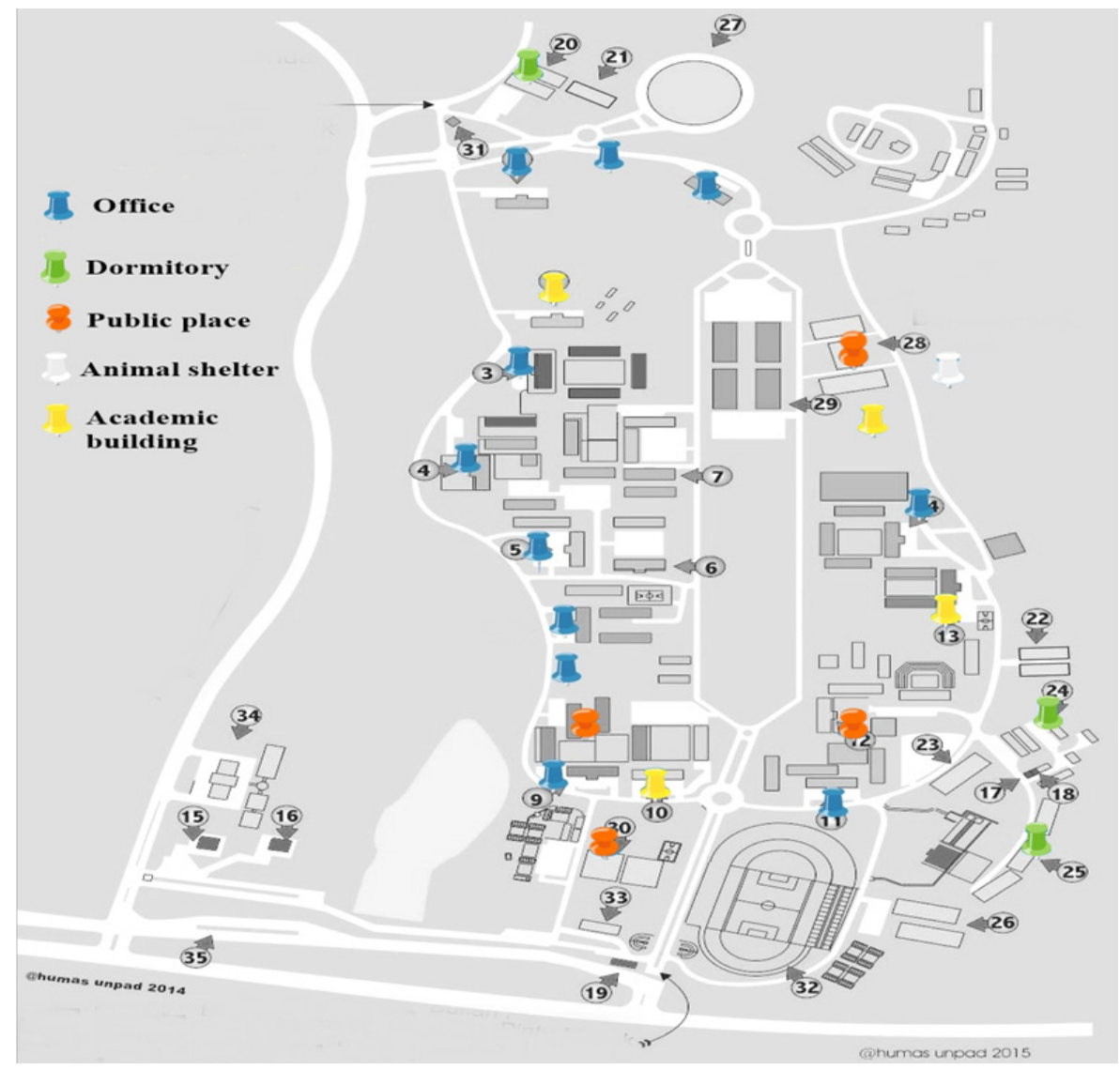

Figure Map of Unpad Jatinangor Campus ${ }^{9}$

Identification of mosquito was using the light microscope, with several tools such as styrofoam, needle, tweezers, paper, and a book of mosquito identification key. This research has obtained the ethical feasibility statement from the Research Ethics Committee of Faculty of Medicine Universitas Padjadjaran with number 17/UN6. C1.3.2/KEPK/PN/2016.

\section{Results}

The study result showed that four species were identified in Unpad Jatinangor campus, namely Anopheles spp., Aedes spp., Culex spp., and Armigeres spp. The number of mosquitoes identified is listed in Table 1. Aedes spp. was the most active mosquito during the day while Culex spp. and Armigeres spp. identified as the most active mosquitoes during the night.

Table 2 shows that mosquitoes identified in locations with high human activities either days or nights. Table 3 illustrates that Culex spp., Armigeres spp., and Aedes spp. dominated by offices, academic building, and dormitory. Table

Table 1 Types and Number of Mosquito Genera Presence in Unpad Jatinangor Campus

\begin{tabular}{|c|c|c|c|c|c|}
\hline \multirow{2}{*}{ Genera } & \multicolumn{2}{|c|}{ Day } & \multicolumn{2}{|c|}{ Night } & \multirow{2}{*}{ Total } \\
\hline & Male & Female & Male & Female & \\
\hline Culex spp. & 100 & 35 & 184 & 88 & 405 \\
\hline Aedes spp. & 2 & 19 & 5 & 7 & 33 \\
\hline Armigeres spp. & o & 8 & 17 & 45 & 70 \\
\hline Anopheles spp. & 4 & 3 & 1 & 2 & 10 \\
\hline
\end{tabular}


Table 2 Number of Mosquito During Day and Night According to Location

\begin{tabular}{lcccc}
\hline \multirow{2}{*}{ Location } & \multicolumn{2}{c}{ Indoor } & \multicolumn{2}{c}{ Outdoor } \\
& Day & Night & Day & Night \\
\hline Offices & 24 & 57 & 31 & 60 \\
Academic building & 10 & 34 & 18 & 74 \\
Public places & 11 & 33 & 35 & 49 \\
Dormitory & 16 & 17 & 14 & 18 \\
Animal shelter & 1 & 4 & 9 & 3 \\
\hline
\end{tabular}

4 confirms that Aedes spp as dengue vector might be found inside and outside the buildings particularly in the day time.

\section{Discussion}

Culexspp. is the mostcommon mosquitoidentified in Unpad Jatinangor campus and followed by Armigeres spp. The previous study by Anwar et al. ${ }^{10}$ showed that most abundant mosquito found in all altitudes above the sea level is usually Culex spp. which can breed and grow in lowland, hilly, or highland area. Jatinangor is a highland area which gives Culex spp. a favorable condition to develop. Another study by Okorie et al. ${ }^{11}$ in the poor waste management system in Southwestern Nigeria also showed that Culex spp. as the most abundant genus found because of Culex spp. might breed on the rice field and in polluted water such as drainage or septic tanks. The environment of Unpad Jatinangor campus where water system, rice field, and bamboos are found in the most area might be chosen as potential breeding sites for this genus. Some drains are clogged with garbage and leaf litter that will attract Culex spp. to breed in. A study by Nurin-Zulkifli et al. ${ }^{12}$ showed an abundance of Armigeres spp. was
Table 4 Number of Mosquito Day and NightAccording to Specific Genera

\begin{tabular}{lrrrc}
\hline \multirow{2}{*}{ Genera } & \multicolumn{2}{c}{ Indoor } & \multicolumn{2}{c}{ Outdoor } \\
& Day & Night & Day & Night \\
\hline Culex spp. & 50 & 110 & 83 & 162 \\
Aedes spp. & 7 & 8 & 14 & 4 \\
Armigeres spp. & 2 & 26 & 6 & 36 \\
Anopheles spp. & 3 & 1 & 4 & 2 \\
\hline
\end{tabular}

found in Sungai Penchala, Malaysia. This is due to the potential breeding sites of Armigeres spp. where bamboos and rice field were widely found in the study area. Armigeres spp. was attracted to water accumulation in bamboos and rice field to breed. Culex spp. and Armigeres spp. are known as the vector of diseases such as filariasis and Japanese encephalitis.

Other genera collected in campus area were Aedes spp. and Anopheles spp. Aedes spp. is well known as a vector of dengue fever, especially Aedes aegypti and Aedes albopictus. The least mosquito collected was Anopheles spp. which was only about ten mosquitoes. Jatinangor area is a highland area which the lowest point is 675 meter and the highest point is 1281 meter above the sea level. The previous study from Pinault and Hunter ${ }^{13}$ showed that Anopheles spp. found in a highland area. The temperature of highland is cooler than the lower area which does not significantly give effect to the development of mosquito. However, some Anopheles spp. still can breed and develop in the cooler area. The other possibility that there is more development in Jatinangor area because some changes including local temperature which give a comfortable environment for Anopheles spp. to grow.

The existence of mosquito determines by

Table 3 Number of Mosquito per Location According to Specific Genera

\begin{tabular}{|c|c|c|c|c|c|c|c|c|c|c|}
\hline \multirow[t]{2}{*}{ Genera } & \multicolumn{2}{|c|}{ Offices } & \multicolumn{2}{|c|}{$\begin{array}{l}\text { Academic } \\
\text { Building }\end{array}$} & \multicolumn{2}{|c|}{$\begin{array}{l}\text { Public } \\
\text { Places }\end{array}$} & \multicolumn{2}{|c|}{ Dormitory } & \multicolumn{2}{|c|}{$\begin{array}{l}\text { Animal } \\
\text { Shelter }\end{array}$} \\
\hline & $\mathbf{I}^{*}$ & $\mathbf{O}^{* *}$ & $\mathbf{I}$ & $\mathbf{O}$ & $\mathbf{I}$ & $\mathbf{O}$ & $\mathbf{I}$ & $\mathbf{O}$ & $\mathbf{I}$ & $\mathbf{O}$ \\
\hline Culex spp. & 60 & 61 & 30 & 74 & 36 & 73 & 30 & 28 & 4 & 9 \\
\hline Aedes spp. & 7 & 15 & 2 & o & 2 & 4 & 2 & 1 & o & o \\
\hline Armigeres spp. & 12 & 15 & 9 & 18 & 6 & 7 & 1 & o & 1 & 1 \\
\hline Anopheles spp. & o & 2 & 3 & o & o & o & 1 & 2 & o & 2 \\
\hline
\end{tabular}

Note: *indoor, ${ }^{* *}$ outdoor 
many factors. One of the factors is the presence of human inside, and their migration. ${ }^{14}$ Offices, academic buildings, dormitories, and few public places in the campus are the places where the mosquitoes are found dominantly, which were more than 100 mosquitoes during collection. This may be because these locations tend to be full of students and faculty's staff. This condition could attract the mosquito to come to the places to find blood for feeding. Faculty's staffs and students usually will spend around 7-8 hours in the campus. Some students might spend time on campus until night which could attract the mosquitoes. The high population of human will attract mosquito to come to the area. Mosquitoes are attracted to human as humans release carbon dioxide and skin odor. Astuti et al..$^{15}$ found that the environment of Unisba campus has not been free of Aedes mosquito. The previous study from Smallegange et al. ${ }^{16}$ showed carbon dioxide is an important factor in attracting mosquito. In this study, baited trap with yeast producing carbon dioxide caught more mosquitoes compared to non-baited trap. Then the number of mosquitoes caught increased when a human added as bait together with the yeast producing carbon dioxide. This shows human attracts mosquito due to carbon dioxide and skin odor.

Another factor contributes to the abundance of mosquitoes in these locations is a suitable environment for mosquito growth such as trees, vegetation, shrubs, drainage, water canals, roof canal, ponds, and garbage (food containers). ${ }^{17}$ Area of Unpad campus filled with trees and vegetation almost at every place. Leaf litter may clog the drainage and roof canal nearby the locations. Garbage such as food container, plastics, bottles, and cans which are not managed well could contribute to mosquito breeding sites. During rain, water will accumulate and attract female mosquito to breed there. ${ }^{17}$

Mosquitoes collected at the dormitory in this study were less than 100. This may because the activity dormitory area is less than in offices, academic building, and public places in the campus area. Additionally, only first-year students stay in the campus dormitory and most students live outside campus. The abundance of people in this area may affect the number of mosquito in dormitory area. ${ }^{18}$ The animal sheds which belong to Faculty of Animal Husbandry also could attract the mosquito to come to the sheds because mosquito also feeds on animal blood which is referred as zoophilic. ${ }^{19}$

Male Culex spp. was much more abundant and very active during the night due to its nocturnal type. The previous study showed that Culex spp. is active throughout the night with the highest peak of biting activity is at 8.00 p.m. -9.00 p.m. ${ }^{20}$ or nocturnal biting habit with irregular peaks. ${ }^{21}$ On the other hand, Aedes spp is very dominantly during the day. The previous study showed that Aedes spp. is the most abundant mosquito that shows diurnal biting pattern especially for species of Aedes aegypti and Aedes albopictus. ${ }^{22}$ In this research, the result showed that the number of Aedes spp. increased dramatically during the night at the dormitory. Result study from Paramasivan et al. ${ }^{22}$ also showed that some Aedes spp. have a nocturnal biting pattern. Hadi et al. ${ }^{23}$ stated that Aedes spp. have night feeding behavior. Another study from Prasetyowati et al. ${ }^{24}$ found that Aedes aegypti activity is detected at night, both indoor and outdoor. This study showed Aedes spp. activity change due to changes in their circadian rhythms by external factors such as light. ${ }^{25}$ The number of Aedes spp. increased in the dormitory at night as students spend time at the dormitory at night, and electrical lighting attracts the mosquito. Collection of Aedes spp. in Unpad campus also showed a high number of female mosquitoes because of only female mosquito feed on blood. The existence of human will attract more female mosquitoes to the area. ${ }^{26} \mathrm{~A}$ male mosquito only feeds on plant nectar instead of human blood. The number of female mosquitoes will contribute to the spread of mosquito-borne disease as only female mosquito bites human.

More Armigeres spp. collected at night compared to during the day since it has a crepuscular biting pattern which active during dawn and dusk. Previous research by Paramasivan et al. ${ }^{22}$ reported that Armigeress ubalbatus shows a typical crepuscular biting pattern with a major peak during the dusk period, which is slightly extended up to mid-night. A minor biting peak was observed during dawn period. Armigeres spp. is the second most dominant mosquito found in the campus since almost every area of faculty and dormitory were filled by trees. Leaves from the trees fell and decompose at the ground and nearest drainage or puddles. Besides leaves, a small rotten branch from a tree also may fallen. Decomposition of leaf litter and rotten tree branch will give high organic content to the area which gives a favorable condition for Armigeres 
spp. to breed. The previous study by Chaves et al. ${ }^{27}$ showed an abundance of Armigeres spp. increases in an area where the ground is rich in leaf litter. It shows that leaf litter is enriching the potential larval habitat of Armigeres mosquito. Another study from Kirti and Kaur et al. ${ }^{28}$ showed that Armigeres spp. larva found on the water with high organic content. Rainfall is also one of the factors to contribute to the abundance of Armigeres spp. in the Unpad Jatinangor campus. During the collection of mosquitoes, rain was falling almost every day in Jatinangor. It is proved by the same study by Chaves et al., ${ }^{27}$ where the rainfall is one contributing factor to the abundance of Armigeres spp. since the eggs which enter diapause during dry condition will hatch due to the rain and lead to the increasing number of Armigeres spp.

Anopheles spp. was found dominantly during the day compared to at night. The result is a contrast to previous studies where most Anopheles spp. have a nocturnal biting pattern with a different peak of activity depending on species. ${ }^{24}$ However, research by Sougoufara et al. ${ }^{29}$ at Dielmo, a rural Senegalese village, showed there was changing the behavior of Anopheles mosquito which human day is biting rate is higher than night biting rate due to use of longlasting insecticidal nets in the study area. The use of nets causes Anopheles mosquito to change their behavior as a day-biting mosquito. The purpose of bed nets gives pressure to mosquito to become day bitter as humans are not using it during the day. Mosquito will find the host at a time where human are more accessible to biting. ${ }^{30}$ There could be changing behavior in Anopheles mosquito at Unpad Jatinangor campus with unknown reason. Result also showed Anopheles spp. found in offices, academic buildings, animal shelter, and dormitory. A further survey of mosquito breeding sites needs to be done in Unpad Jatinangor campus. So, prevention can be taken by eliminating the possible breeding sites. The use of windows net as a protection against mosquito also should be considered.

\section{Conclusion}

Culex spp., Aedes spp., Armigeres spp., and Anopheles spp. were genera of mosquitoes identified in Unpad Jatinangor campus. Aedes spp. was the most active genus during the day while Culex spp. and Armigeres spp. were the most active genera at night.

\section{Conflict of Interest}

The authors declare no conflict of interests.

\section{Acknowledgement}

Thank you to staffs in Parasitology Laboratory, Faculty of Medicine Unpad, surveyors, and colleagues who willingly helped and gave supports during the research. Appreciations to the University that has given internal grants for supporting this research.

\section{References}

1. McBride CS, Baier F, Omondi AB, Spitzer SA, Lutomiah J, Sang R, et al. Evolution of mosquito preference for humans linked to an odorant receptor. Nature. 2014;515(7526):222-7.

2. Wu X, Lu Y, Zhou S, Chen L, Xu B. Impact of climate change on human infectious diseases: empirical evidence and human adaptation. Environ Int. 2016;86:14-23.

3. Aplikasi Komunikasi Data, Ministry of Health of Republic of Indonesia [Internet]. 2015 [cited 2016 March 13]. Available from: https://komdat. kemkes.go.id/lama/index_dashboard. php? folder $=$ reports\&pg $=$ rptKomGenera tor\&tahun $=2015 \&$ kode_property $=001$ 000058,001-000059,001-000060,001oooo61\&jenis_wilayah=kabupaten\&field_ baris $=$ wilayah\&field_kolom $=$ periode_ indikator\&seluruh_data $=$ o\&kode_ provinsi $=15 \&$ kode_kabupaten $=149$.

4. Dinas Kesehatan Kabupaten Sumedang. Laporan demam berdarah. Sumedang: Dinas Kesehatan Kabupaten Sumedang; 2015.

5. Kasus penderita DBD di Kab. Sumedang meningkat [Internet]. Galamedia News. 2015 [cited 2016 April 4]. Available from: http://m.galamedianews.com/daerah/8217/ kasus-penderita-dbd-di-kab-sumedangmeningkat.html.

6. Waspada wabah DBD meningkat [Internet]. Sumedang Express. 2016 [cited 2016 April 4]. Available from: http://www. sumedangekspres.com/waspada-wabahdbd-meningkat.

7. Puskesmas Jatinangor. Laporan tahunan. Jatinangor: Puskesmas Jatinangor; 2015.

8. Huang YJS, Higgs S, Horne KM, Vanlandingham DL. Flavivirus-mosquito 
interactions. Viruses. 2014;6(11):4703-30.

9. Denah Kampus Unpad Jatinangor [Internet]. 2015 [cited 2016 Nov 27]. Available from: http://www.unpad.ac.id/universitas/rutedan-peta/denah-kampus-unpad-jatinangor.

10. Anwar C, Ghiffari A, Kuch U, Taviv Y. The abundance of mosquitoes (family: Culicidae) collected in an altitudinal gradient in South Sumatra, Indonesia. In: Rahman MA, Gaidamashvili M, editors. Proceeding International Conference on Agricultural, Ecological and Medical Sciences (AEMS2015). Feb. 10-11, 2015 Penang (Malaysia). Penang: International Institute of Chemical, Biological \& Environmental Engineering (IICBEE); 2015. hlm. 28-30.

11. Okorie PN, Popoola KO, Awobifa OM, Ibrahim KT, Ademowo GO. Species composition and temporal distribution of mosquito populations in Ibadan, Southwestern Nigeria. J Entomol Zool Stud. 2014;2(4):164-9.

12. Nurin-Zulkifli IM, Chen CD, Wan-Norafikah O, Lee HL, Faezah K, Izzul AA, et al. Temporal changes of Aedes and Armigeres populations in suburban and forested areas in Malaysia. Southeast Asian J Trop Med Public Health. 2015;46(4):574-85.

13. Pinault LL, Hunter FF. Malaria in highlands of Ecuador since 1900. Emerg Infect Dis. 2012;18(4):615-22.

14. Yosefina Dota T, Syahribulan, Umar MR. Eksistensi dan sebaran nyamuk aedes aegypti dan aedes albopictus di kampus Universitas Hasanuddin Makassar. JEK. 2013;12(2):8794.

15. Astuti RDI, Ismawati, Siswanti LH, Suhartini A. Sebaran vektor penyakit demam berdarah (Aedes aegypti) di Kampus Universitas Islam Bandung. GMHC. 2016;4(2):82-6.

16. Smallegange RC, Schmied WH, van Roey KJ, Verhulst NO, Spitzen J, Mukabana WR, et al. Sugar-fermenting yeast as an organic source of carbon dioxide to attract the malaria mosquito Anopheles gambiae. Malar J. 2010;9:292.

17. Naz R, Maryam A, Shabnam. Population dynamics of mosquitoes in various breeding habitats at University of Peshawar campus, Khyber Pukhtunkhwa Pakistan. J Entomol Zool Stud. 2014;2(2):189-95.

18. Rochlin I, Faraji A, Ninivaggi DV, Barker CM, Kilpatrick AM. Anthropogenic impacts on mosquito population in North America over the past century. Nat Commun. 2016;7;13604.

19. Getachew D, Tekie H, Gebre-Michael T, Balkew M, Mesfin A. Breeding sites of Aedes aegypti: potential dengue vectors in Dire Dawa, East Ethiopia. Interdiscip Perspect Infect Dis. 2015;2015:706276.

20. Bashar K, Tuno N, Ahmed TU, Howlader AJ. Blood-feeding patterns of Anopheles mosquitoes in a malaria-endemic area of Bangladesh. Parasit Vectors. 2012;5:39.

21. Rogozi E, Ahmad RB, Ismail Z. Biting activity cycles of some antropophilic mosquito species in Malaysia. J Int Environ Appl Sci. 2012;7:5.

22. Paramasivan R, Philip SP, Selvaraj PR. Biting rhythms of vector mosquitoes in a rural ecosystem of South India. Int $\mathrm{J}$ Mosquito Res. 2015;2(3):106-13.

23. Hadi UK, Soviana S, Gunandini DD. Aktivitas nokturnal vektor demam berdarah dengue di beberapa daerah di Indonesia. J Entomol Indones. 2012;9(1):1-6.

24. Prasetyowati H, Marina R, Hodijah DN, Widawati M, Wahono T. Survey jentik dan aktifitas nokturnal Aedes spp. di Pasar Wisata Pangandaran. JEK. 2014;13(1):33-42.

25. Meireles-Filho ACA, Kyriacou CP. Circadian rhythms in insect diseases vectors. Mem Inst Oswaldo Cruz. 2013;108(Suppl 1):48-58.

26. Olorunniyi OF. Abundance and diversity of mosquito genera at Ilokun and Irasa. J Bio Innov. 2016;5(3):379-85.

27. Chaves LF, Imanishi N, Hoshi T. Population dynamics of Armigeres subalbatus (Diptera: Culicidae) across a temperate altitudinal gradient. Bull Entomol Res. 2015;105(5):589-97.

28. Kirti JS, Kaur S. Prevalence and distribution of Armigeres subalbatus (Coquillett) in Punjab. Int J Fauna Biol Stud. 2015;2(3):447.

29. Sougoufara S, Diédhiou SM, Doucouré S, Diagne N, Sembène PM, Harry M, et al. Biting by Anopheles funestus in broad daylight after use of long-lasting insecticidal nets: a new challenge to malaria elimination. Malar J. 2014;13:125.

30. Rund SSC, O’Donnell AJ, Gentile JE, Reece SE. Daily rhythms in mosquitoes and their consequences for malaria transmission. Insects. 2016;7(2):14. 